\title{
The Correlation between Self-Confidence of the Undergraduate EFL Students and Their Speaking Achievement
}

\author{
Rizkie Mauly Audina \\ Universitas Islam Negeri Raden Fatah Palembang \\ rizkiemauly@gmail.com \\ Amalia Hasanah \\ Universitas Islam Negeri Raden Fatah Palembang \\ amaliahasanah uin@ radenfatah.ac.id \\ Deta Desvitasari \\ Universitas Islam Negeri Raden Fatah Palembang \\ detadesvitasari_uin@ radenfatah.ac.id
}

\begin{abstract}
The aims of this study were to investigate whether there is a correlation between SelfConfidence with EFL students' speaking achievement. The participants of this study were the Undergraduate EFL Students of UIN Raden Fatah Palembang. purpose. The participants that were chosen can meet certain criteria from this study. In this study, the student's selfconfidence and their speaking achievement are correlated. Therefore, in order to know the students' speaking achievement, a group of students who had already taken the informal speaking courses from the population were considered as the sample. Nonetheless, most of the third semester students have already finished the informal speaking class on last semester and they are on the next level of speaking class on this semester. Quantitative method was used in this study. The data gained from self-confidence questionnaire and the list of students' speaking achievement was analyzed by using SPSS. The result of the study showed that there is no significant correlation and there is no significance influence between selfconfidence of the undergraduate EFL students with their speaking achievement. The researchers of this study recommends other researchers to make sure the respondents are in well condition such as feeling comfortable while taking the data. Furthermore, it is recommended that other researchers to do and to extend more variables in order to reveal any aspects that can support and enhance the quality of researches in speaking skill.
\end{abstract}

Keywords: undergraduate EFL students, self-confidence, speaking achievement

\section{A. Introduction}

People need English to access information, broaden knowledge and promote international relationship in order to fulfill their expectation to meet future challenges. Harmer (2007, p.15) in his book said that English is much used in each part of aspect in people's life, such as in art, economic field, information exchange, and social knowledge aspect. Richard (2007, p.2) emphasizes that it is important for people to learn English because it is the language of globalization, commerce and trade media, pop culture, different 
motivation for learning. In short, understanding and knowing how to use English properly is really important in people's life.

Speaking is the skill that will be discussed in this research. Brown and Yule (2001) claimed in their book that speaking is to express needs - request, information, service, etc (p.25). Students are obliged to communicate the language effectively since this latter plays a big role in learning a language, for that reason speaking skill has always been part of the classroom course. Furthermore, people like to judge the success of learning language by seeing the ability to express their ideas orally. Sara (2015), states in her study speaking has become an essential skill that educational systems have to focus on by which students can pool or exchange information, share ideas and learn more about language (p.8). It is also supported by Richard (2008, p.16), assert that speaking is one of productive skills where this aspect has become a parameter of successful teaching and learning in classroom. In short, speaking skill has been always a demanding task that students need to master and by making the students be able to speak English accurately and fluently in terms of communication is the main goal of English language teaching.

In Indonesia, English is spoken, written and studied as a foreign language. English has become a compulsory subject taught in Indonesia started from elementary to university levels that indicates students in Indonesia have studied English for many years. English Education Program of UIN Raden Fatah also provides speaking classes that consist of three levels for the students. It is learned during three semesters start from the second semester until the fourth semester. The students learn speaking English in specific class for each semester. However, producing a good speaking skill is not an easy task for students, especially to whom English is not their first language. As Brown and Yule (2001, p.25) states learning to talk in the foreign language is often considered as one of the most difficult aspects of language learning for the teacher to support their students. It is supported by Alonso (2012, p.19) in his study assert there is a frustrated reality for many EFL students that they still feel difficult to use English in speaking even though they have learned it for many years. By knowing this, teachers have tried to apply various activities to have their students fluent in speaking by giving a task that make them practice, such as group presentation, peer friends conversation, or through debate in class activities to help students practice their speaking skill. 
One affective factor which has great impact on the development of the speaking skill is self-confidence. Confidence means firm trust in the abilities (Oxford Dictionary, 2008). Adalikwu (2012, p.5) stated self-confidence can be summed up as the belief that a person has in their ability to succeed at a task, based on whether or not they have been able to perform that task in the past. Azmandian (2010, p.80) in his book stated self-confidence is a major first stop along the path of successful life. In addition, Eldred, Ward, Snowdon \& Dutton (2004, p.6) said that self-confidence is one of the keys to the successful development of literacy, language, and numeracy skills through the skills for life strategy. In conclusion, having self-confidence in one self means belief in our own ability, having self-confidence can help students tell their ideas more effectively and fluently especially in speaking skill.

Students who have general self-confidence will be able to overcome fears or negative thoughts, so they will be easy to communicate especially in the oral activities. In addition, Kakepoto (2012, p.71) affirmed that confidence is an essential aspect of any good presentation. It provides impetus to speakers to communicate his or her ideas effectively. Students should be aware about the importance of self-confidence because it has great impact on their learning process in particular, and in everything they do in general. This is the reason why self-confidence is one of the most influential variables which can affect learning process in speaking field.

Based on the explanation above, the writer is interested in doing an investigation to the issue whether there is a significant correlation between self-confidence and speaking achievement. Specifically, the writer wants to carry out a study on self-confidence and speaking achievement of the English Education Study Program Students of UIN Raden Fatah Palembang entitled "The Correlation between Self-Confidence of the Undergraduate EFL Students of UIN Raden Fatah Palembang and Their Speaking Achievement”.

\section{B. Literature Review}

\section{Concept of Speaking}

In studying English as a tool of communication, it contains four language skills. They are listening, speaking, writing and reading. Brown and Yule (2001) state that speaking is to express needs - request, information, service, etc (p.25). Speaking is an essential collaborative and interactive process. It is an exchange between the speakers. We may finish each other's comments, interrupt, or disagree with or extend what is said (Cole, 2007, p.12). 
McKay (2008) add speaking is not merely opening mouth and say words and sentences, but it includes a cultural background of a target language which is spoken to get meaningful interaction (p.179). Speaking is not only producing sounds but also a process of achieving goals and transferring messages. The speaker says words to their listener not only to express what on his mind but also to express what he needs.

Speaking has become an essential skill which students can exchange information, share ideas and learn more about language. Richards (2012) in his book, summed up that the development of good speaking skills is no longer a bonus for language learners, but an essential aspect of their language-proficiency development because it has a direct impact on the personal and professional success of many of them (as cited in Kanza, 2016, p.8). Many researchers gave the speaking skill priority in their researches because of its important role in the process of teaching and learning foreign language.

Speaking is an essential collaborative and interactive process. It is an exchange between the speakers. We may finish each other's comments, interrupt, or disagree with or extend what is said (Cole, 2007, p.12). McKay (2008) add speaking is not merely opening mouth and say words and sentences, but it includes a cultural background of a target language which is spoken to get meaningful interaction (p.179). Speaking is not only producing sounds but also a process of achieving goals and transferring messages. The speaker says words to their listener not only to express what on his mind but also to express what he needs.

Speaking is considered as a crucial part of the students' language learning process. It helps them to expand their knowledge of the language in order to use it in daily life. Speaking in another language is a wonderful experience and it is likely what the students are aiming for. The sense of accomplishment after completing a conversation in a different language is greater than the students ever imagine. Ur (1996) states, speaking is one of the most important skill of all the four language skills because individuals who learn a language are referred to as the speakers of the language, as if speaking included all other kinds of knowing (p.120).

There are various explanations about factor that hinder students' speaking skill. It includes the internal factor and external factor. 
1. Affective factor is the emotional side of human behavior. Psychological factors such as anxiety, shyness, lack of confidence, lack of motivation, and fear of making mistakes are the factors that commonly affecting students' speaking skill.

2. In linguistic, the term competence is used to describe the learners' capacity to produce a language (Hamerka, 2009, p.14). Linguistic competence here includes the vocabulary, pronunciation, and grammar. Lack of these linguistic competence mostly affects students' speaking skill and has leads many students to have a low speaking skill.

3. Topical knowledge is the speakers' knowledge of relevant topical information. Harmer (2007), states that if the teacher give a suitable topic and task, the students will often participate freely and enthusiastically in the lesson (p.345). Vice versa, if the students being asked to do a speaking performance and they are lack of knowledge related to the topic of a lesson, it will eventually make them do not know what to say and, in the end, they will not participate in the classroom activities.

4. A good language environment can effectively promote learning. Creating a good class atmosphere, making the students feel at ease will eventually led them to participate in class more. It will also make them participate more.

5. Most of the students are expecting the teachers to give them feedback on their performance. In giving the feedback a teacher needs to use it carefully, we cannot correct every single mistake that the students did or onto the level of interrupting them in the middle of their performance in front of lots of people because if the students are corrected all the time, they can find this very demotivating and makes them afraid to speak.

There are also explanations about problems in speaking skill, they are:

1. Inhibition. Unlike reading, writing, and listening activities, speaking requires some degree of real-time exposure to an audience.

2. Nothing to say. Even if they are not inhibited, learners often complain that they cannot think of anything to say: they have no motive to express themselves beyond the guilty feeling that they should be speaking.

3. Low or uneven participation, when only one participant can talk at a time if he or she is to be heard; and in a large group this means that each one will have only very little 
talking time. This problem is compounded by the tendency of some learners to dominate, while others speak very little or not at all.

4. The use of mother tongue. In classes where all, or a number of, the learners share the same mother-tongue, they may tend to use it: because it is easier, because it feels unnatural to speak to one another in a foreign language, and because they feel less 'exposed' if they are speaking their mother tongue. If they are talking in small groups, it can be quite difficult to get some classes - particularly the less disciplined or motivated ones - to keep to the target language.

\section{Concept of Self-Confidence}

One affective factor which has great impact on the development of the speaking skill is self-confidence. Confidence means firm trust in the abilities (Oxford Dictionary, 2008). According to Brown (2000) and Skehan (1989), the affective factor is the emotional side of human behavior and it involves a variety of personality aspects, such as emotion, motivation, attitude, anxiety, personality, and self-confidence (as cited in Al-Hebaish, 2012, p.60). Among these, self-confidence is one of the most influential variables which affect learning.

Lland (2013) defined, the word "confidence" originated from the Latin word "confidentia" meaning "to trust" and "to have faith" (p.11). Self-confidence is a personal factor that pays a supportive role in the achievement of language learning. Self-confidence is like the foundation of a building; if they are not enough, even the best technology will be insufficient to build solid walls over them (Mustafa, 2015, p.23). When students have selfconfidence about their abilities regardless to their past experiences, they lightly will succeed in their learning.

Self-confidence is a personal factor that pays a supportive role in the achievement of language learning. Self-confidence is like the foundation of a building; if they are not enough, even the best technology will be insufficient to build solid walls over them (Mustafa, 2015, p.23). It is an attitude which allows us to have a positive and realistic perception of ourselves and our abilities. Therefore, self-confidence can be concluded as someone's belief in their ability, despite the past experience whether they succeed or not in doing task. When students have self-confidence about their abilities regardless to their past experiences, they lightly will 
succeed in their learning. In short, where there is self-confidence, there will be good communication.

There are explanations about factor affecting Self-Confidence. It includes the internal factor and external factor.

1. Self-Image, the way a person see himself can affect his confidence, if in his minds he sees himself can do something, it will make him ready to take challenges, deal with hard situations and can find a way to fix what goes wrong in his life, that is a total selfconfidence.

2. Life experiences, once a person know he is good at something, even though he makes a mistake one or two, when he knows deep inside that he can get back to where he was, he will still continue to improve.

3. Environment, negative environment where people are harsh or even abusive to one another are toxic. When people are living with someone who puts them down on a regular basis, people are unable to find strength in themselves. A person needs to be supported by people around him, including his family, a friend, or people in daily basis. When a person does not have those supportive people who can give support to him, it will decreased or might be erased his self-confidence completely.

4. Education, a person cannot feel confident unless he knows what he needs to know. Goldsmith (2010) in his book stated that a person cannot feel confident unless he knows what he needs to know (p.28). He also added a person need to get educated, learn, do a research, and never stop reading.

\section{Research Methodology Research Design}

In this study, the writer conducted correlational research. According to Creswell (2012), "A correlation is a statistical test to determine the tendency or pattern for two (or more) variables or two sets of data to vary consistently" (p. 338). Moreover, Creswell (2012) adds the purpose of a prediction research design is to identify variables that will predict an outcome or criterion. This prediction research design found out the correlation between selfconfident as a predictor variable and speaking achievement of the students of English Education Study Program students of UIN Raden Fatah Palembang as the criterion or outcome variable. 
This research used interview and students' speaking achievement as the instruments. The researcher found out there is no significant correlation between self-confidence of the undergraduate EFL students pf UIN Raden Fatah Palembang with their speaking achievement.

\section{Research site and participants}

This research was conducted at UIN Raden Fatah in Palembang. Purposeful sampling was used in this study. Purposive sampling (judgmental sampling) is used in both qualitative and quantitative research (Johnson \& Christensen, 2012, p. 235). Based on Creswell (2005, p. 204), in this method, the researchers selected individuals and sites to learn and understand about the topic whether they were "information rich".

The researcher used this sampling because the participants were selected based on some purpose. The participants that were chosen can meet certain criteria from this study. In this study, the student's self-confidence and their speaking achievement are correlated. Therefore, in order to know the students' speaking achievement, a group of students who had already taken the informal speaking courses from the population were considered as the sample. Nonetheless, most of the third semester students have already finished the informal speaking class on last semester and they are on the next level of speaking class on this semester. Thus, the samples of this research were all of the active students in the third semester.

\section{Data collection and analysis}

This research used self-confidence questionnaire and students' speaking achievement data here means the score of the students as the instruments. The data taken was speaking achievement score from 4 classes of the student academic year of 2019 , to be exact their informal speaking achievement score. In this research, the researcher used the readymade questionnaire which was taken from University of Tennessee honors thesis project Questionnaires entitled Academic self-confidence scale, a psychological study in two parts by Holly Kristine Jones which was conducted in 2001. However, from the total 29 questions of the questionnaire, the researcher only used 19 items that already translated into Bahasa and gave try out by Zikrullah (2017) in order to minimized miss interpretation. 
The data in this study have been analyzed using the SPSS 25. As for the statistical analysis of the first research question, data related to numbers, frequencies, means and percentages were computed to identify the levels of the students' self-confidence. Furthermore, for each positive statement the researcher has assigned; "Strongly Disagree" 1; "Disagree" 2; "Neutral" 3; "Agree" 4; "Strongly Agree" 5. The participation level intervals have been found using minimum and maximum score. As a result of the computation, the interval scale of minimum score is 19 and maximum score is 95 . From the minimum and the maximum score, the researcher quoted the interval scale from Zikrullah (2017), there are three categories, those are high self-confidence, medium self-confidence and low selfconfidence. The interval scales in the study are shown in the Table 1 below.

Table 1. Interval Scale of the Students' Self-Confidence

\begin{tabular}{cc}
\hline Category & Score Interval \\
\hline High & $65-95$ \\
\hline Medium & $33-64$ \\
\hline Low & $19-32$ \\
\hline
\end{tabular}

The participation level intervals have been found using minimum and maximum score. As a result of the computation, the interval scale of minimum score is 0 and maximum score is 90 . From the minimum and the maximum score, the interval scale divided into five categories, those are very good (A), good (B), average (C), poor (D) and very poor (E). The interval scales in the study are shown in the Table 2 below.

Table 2. Interval Scale of the Speaking Achievement

\begin{tabular}{cc}
\hline Category & Score Interval \\
\hline Very good & $80-90$ \\
\hline Good & $70-79$ \\
\hline Average & $60-69$ \\
\hline
\end{tabular}


$50-59$

Poor

Very poor $\quad 0-49$

\section{Results and Discussion}

\section{Results}

Results of Students' Self-Confidence Questionnaire

The findings of this study were obtained from the questionnaire and the students' speaking achievement of the students of English education study program of UIN Raden Fatah Palembang academic year of 2019. The total active students in English Education Study Program academic year of 2019 were 128 students. However, 75 students participated in this study; the other students did not feel disposed to be participants and were not present when the researcher was conducting this study. The scores were tabulated in the form of Likert scale with 5 options grading. In scoring the students' self-confidence, 19 items were calculated based on the scale.

The data presented are the mean score, the frequency, and the standard deviation of the result of the students' self-confidence. The result of self-confidence questionnaire can be seen in the descriptive statistics below:

Table 3. Descriptive Statistic of The Students' Self-Confidence Measured.

\begin{tabular}{|c|c|c|c|c|c|c|}
\hline \multirow[t]{2}{*}{ Variable } & \multirow[t]{2}{*}{ Category } & Frequency $(\%)$ & Mean & SD & \multirow[t]{2}{*}{ Min } & \multirow[t]{2}{*}{ Max } \\
\hline & & $\begin{array}{c}\mathrm{N} \\
(75)\end{array}$ & $\begin{array}{c}\mathrm{N} \\
(75)\end{array}$ & $\begin{array}{c}\mathrm{N} \\
(75)\end{array}$ & & \\
\hline \multirow{3}{*}{$\begin{array}{l}\text { Students' } \\
\text { Self- } \\
\text { Confidenc } \\
\text { e }\end{array}$} & High & $\begin{array}{c}60 \\
(80 \%)\end{array}$ & \multirow{3}{*}{69.24} & \multirow{3}{*}{7.50} & \multirow{3}{*}{47} & \multirow{3}{*}{83} \\
\hline & Medium & $\begin{array}{c}15 \\
(20 \%)\end{array}$ & & & & \\
\hline & Low & - & & & & \\
\hline
\end{tabular}

Source: Primary data processed 2020

Based on the descriptive statistical analysis of self-confidence questionnaire above, the researcher found out that the mean score of the third semester students' self-confidence at English Education Study Program of UIN Raden Fatah Palembang was 69.24. The standard 
deviation of the students' self-confidence was 7.50 with the maximum score was 83 and the minimum score was 47 . Based on the table above, there were $60(80 \%)$ students who had high self-confidence, 15 (20\%) students who had medium self-confidence and none of the students who had low self-confidence. The results indicated that most of the third semester students of English Education Study Program of UIN Raden Fatah Palembang have high level of self-confidence.

\section{Result of Students' Speaking Achievement}

From 4 classes of academic year of 2019, there are 128 students in total. Since only 75 students who fill the questionnaires which the researcher analyzed, the researcher also only analyzed 75 students' speaking achievement.

The result of descriptive statistics of speaking achievement can be seen below:

Table 4. Descriptive Statistic of The Students' Speaking Achievement

\begin{tabular}{|c|c|c|c|c|c|c|}
\hline \multirow[t]{2}{*}{ Variable } & \multirow[t]{2}{*}{ Category } & Frequency $(\%)$ & Mean & SD & \multirow[t]{2}{*}{ Min } & \multirow[t]{2}{*}{$\operatorname{Max}$} \\
\hline & & $\begin{array}{c}\mathrm{N} \\
(75) \\
\end{array}$ & $\begin{array}{c}\mathrm{N} \\
(75)\end{array}$ & $\begin{array}{c}\mathrm{N} \\
(75)\end{array}$ & & \\
\hline \multirow{5}{*}{$\begin{array}{l}\text { Students' } \\
\text { speaking } \\
\text { achievement }\end{array}$} & Very good & $\begin{array}{c}34 \\
(45.3 \%) \\
\end{array}$ & \multirow{5}{*}{79.08} & \multirow{5}{*}{5.81} & \multirow{5}{*}{56} & \multirow{5}{*}{87} \\
\hline & Good & $\begin{array}{c}38 \\
(50.6 \%)\end{array}$ & & & & \\
\hline & Average & - & & & & \\
\hline & Poor & $\begin{array}{c}3 \\
(4 \%) \\
\end{array}$ & & & & \\
\hline & Very poor & - & & & & \\
\hline
\end{tabular}

Source: Primary data processed 2020

Based on the descriptive statistical analysis of speaking achievement above, the researcher found out that the mean score of the third semester students' speaking achievement at English Education Study Program of UIN Raden Fatah Palembang was 79.08. The standard deviation of the students' self-confidence was 5.81 with the maximum score was 87 and the minimum score was 56. Based on the table above, there were 34 (45.3\%) students who had very good speaking achievement, 38 (50.6\%) students who had good speaking achievement, 3 (4\%) students who had poor speaking achievement and none of the students had average or very 
poor speaking achievement. The results indicated that most of the third semester students of English Education Study Program of UIN Raden Fatah Palembang have good speaking achievement.

\section{Statistical Analyses}

There were three statistical analyses that the researcher applied in this study:

1. The statistical analysis of normality and linearity

2. The statistical analysis of correlation analysis between students' self-confidence and their speaking achievement of all participants.

3. The statistical analysis of regression analysis between students' self-confidence and their speaking achievement of all participants.

Normality test and linearity test were conducted by using SPSS $25^{\text {th }}$ version for windows. The parametric statistic, in term of correlation and regression were used in this research, it was important to see if the distribution of data were normal for each variable and linear between variables.

The results of normality test indicated that the data from both variables were 0.056 . In conclusion, based on the result of the significance score which is higher than 0.05 , it means the data distribution were all normal. Based on the result of linearity test, it showed that the deviation from linearity between self-confidence and speaking achievement (sig) was 0.857 . In conclusion, based on the result which is higher than 0.05 , it means the data is linear.

Then, to find out the contribution, regression analysis was applied. In calculating the data, the writer applied statistical analysis by using Statistical Package for Social Science (SPSS) version 25.0. In order to answer the first research question whether there is any significant correlation between self-confidence and speaking achievement in informal speaking class of the third semester students of English Education Study Program of UIN Raden Fatah Palembang, the researcher did a statistical analysis by using Pearson's Product Moment Correlation. From all of results of the data, it was found that the value of r-obtained correlation coefficient of self-confidence and speaking achievement was 0.058 and the significance probability is 0.623 . To describe it, the value of r-obtained should be consulted to the value of $r$-table. If the value of $r$-obtained is greater than value $r$-table $(0.227)$ and $p$ (probability) is less than $\alpha$ (alpha) 0.05 , the researcher concluded there is no correlation 
between students who have high self-confidence and their speaking achievement, it means there is no relationship in this research.

After the first research question was answered, the second research question needs to be answered, how much self-confidence contributed to students' speaking achievement of the English Education Study Program of UIN Raden Fatah Palembang? However, the second research question is no need to be answer, because there was no significant correlation between self-confidence and speaking achievement of the English Education Study Program students of UIN Raden Fatah Palembang.

\section{Discussion}

From analizing the data using SPSS, the researchers found out and would be discussed more in detail. Based on the findings and interpretations of the study, there are some conclusions can be drawn: There was no significant correlation between students' selfconfidence and their speaking achievement of the Undergraduate EFL Students of English Education Study Program at UIN Raden Fatah Palembang. It also can be concluded that there was no significant influence of students' self-confidence on their speaking achievement. It means that students who have high self-confidence do not determine they will also achieve high speaking achievement. Same goes to the students who have medium level of selfconfidence, do not determine they will get average or even low speaking achievement score. In this study, the other factors such as motivation, anxiety, classroom atmosphere and teaching method also gave dominant influence through speaking achievement. Therefore, students' self-confidence is not the only factor which can affect students' speaking achievement.

Based on the findings on this study shown on the previous section, the researcher found out there was no correlation between self-confidence and speaking achievement of the students on academic year of 2019 of English Education Study Program of UIN Raden Fatah Palembang. The researcher can claim that the students with high self-confidence or low selfconfidence is not guarantee can get a high or low speaking achievement score.

In short, all of the data in this have strengthened that self-confidence did not give big influence in speaking achievement of the students of academic year 2019 of English Education Study Program of UIN Raden Fatah Palembang. On other hand, there was no 
significant correlation between self-confidence and speaking achievement of the students of academic year 2019 of English Education Study Program of UIN Raden Fatah Palembang.

Finally, it can be interpreted that the students of academic year 2019 speaking achievement did not get affected by their self-confidence level. Furthermore, there was no a significant correlation between self-confidence and speaking achievement and there was no significant contribution of self-confidence to speaking achievement students of English Education Study Program of UIN Raden Fatah Palembang.

\section{Conclusion and Recommendations}

Here in this study the researcher found very weak correlation between self-confidence and speaking achievement, but it does not mean self-confidence does not affect any academic achievement. Somehow considering the effect of psychological field such as self-confidence, or grammatical field such as grammar, there will be some benefit for both the students and of course, the teacher too.

For language instructors, especially for those who teach speaking courses can support the students by reminding them to have positive thoughts and fight negative views and beliefs. Furthermore, considering that speaking as one of productive skills, the teachers have to motivate the students to practice speaking a lot. As the researcher explain before, a good feedback can make students feel better.

To achieve better finding, the researcher of this study recommends other researchers to make sure the respondents are in well condition such as feeling comfortable while taking the data. Furthermore, it is recommended that other researchers to do and to extend more variables in order to reveal any aspects that can support and enhance the quality of researches in speaking skill.

\section{References}

Adalikwu, C. (2012). How to build Self-Confidence, happiness and health. AuthorHouse.

Al-Hebaish, S. M. (2012). The correlation between general self confidence and academic achievement in the oral presentation course. Taibah University, Saudi Arabia.

Anthony, R (2003). The ultimate secrets of total self-confidence. Total Success Publishing Brisbane

Arango, P. H. (2015). Students' self confidence as a way to improve oral production in the tenth grade students at ricaurte school. Libre University, Columbia 
Asyura, F. (2019). The relationship between self-confidence and speaking performance of second semester students of English department UNISMA. Malang.

Azmandian, A (2010). Think yourself successful .McGraw hill, United States.

Brown, H. D. (2001). An interactive approach to language pedagogy $\left(2^{\text {nd }}\right.$ ed). Pearson Edition.

Brown, H. D. (2004). Language assessment: Principle and classroom practices (4th ed). Pearson Edition.

Cohen, L., Manion, L., \& Morrison, K. (2007). Research method in education (6 ${ }^{\text {th }}$ ed.). Madison avenue, Inc.

Cole, D., Ellis, C., Mason, B., Meed. J., Record. D., Rosseti. A., \& Willcocks. G. (2007). Teaching speaking and listening: a toolkit for practitioners. portishead press

Creswell, J. W. (2012). Research design: qualitative, quantitative and mixed methods approaches $\left(3^{\text {rd }} \mathrm{Ed}\right)$. Sage Publications.

Eldered, J., Ward, J., Snowdon, K., \& Dutton, Y. (2004). Catching confidence: The nature and role of confidence-ways of developing and recording changes in the leraning context. NIACE.

Harner, J. (1998). How to teach English. Longman

Harmer, J. (2001). The practice of English language teaching. Longman.

Kanza, D. (2016). The importance of self-confidence in enhancing students' speaking skill. Mohammed Kheider University of Biskra, Biskra.

Laras. (2019). The correlation of eighth grade students' self-confidence level and speaking skill at SMP YAPIPA Serpong, Tangerang. Univeristas Muhammadiyah, Tangerang, Indonesia.

Lasiyah. (2017). The correlation between self-confidence and speaking achievement of the Undergraduate Students of English Education Study Program, (Undergraduate's thesis). UIN Raden Fatah Palembang, Palembang, Indonesia.

Mustafa, E. (2015). Psychological factor affecting Sudanese EFL learners' oral performance. A case study of Sudan University of Science and Technology. Sudan University of Science and Technology, Sudan.

Nasih. (2019). The correlation between self-confidence and speaking performance of the fourth semester students of English department of university of Islam Malang. University of Islam, Malang, Indonesia.

Oxford. (2008). Oxford-Dictionary ( $4^{\text {th }}$ ed.)

Preston, D. L. (2001). 365 Steps to self confidence. United Kingdom: How To Book.

Richards, J. C. (2008). Teaching listening and speaking: From theory to practice. Cambridge University Press

Sara, B. (2015). Investigating the effects of EFL students' self confidence on their oral performance. Mohammed Kheider University of Biskra, Biskra.

Tridinanti, G. (2018). The Correlation Among Speaking Anxiety, Self-Confidence and Speaking Achievement of Undergraduate EFL Students of Tridinanti University Palembang. Palembang.

Ur, P. (1991). A course in language teaching: practice and theory. United Kingdom: Cambridge University Press.

Wright, J. H. (2008). Building self-confidence with encouraging words. United States of America: Total Recall Publications. 
Jadila: Journal of Development and Innovation

E-ISSN: 2723-6900

in Language and Literature Education

P-ISSN: 2745-9578

Publisher: Yayasan Karinosseff Muda Indonesia

Volume 1 Number 4, 2021

Page: $518-533$

Zikrullah. (2017). The correlation between self-confidence and paragraph writing achievement of English Education Study Program Students, (Undergraduate's thesis). Sriwijaya University, Palembang, Indonesia. 